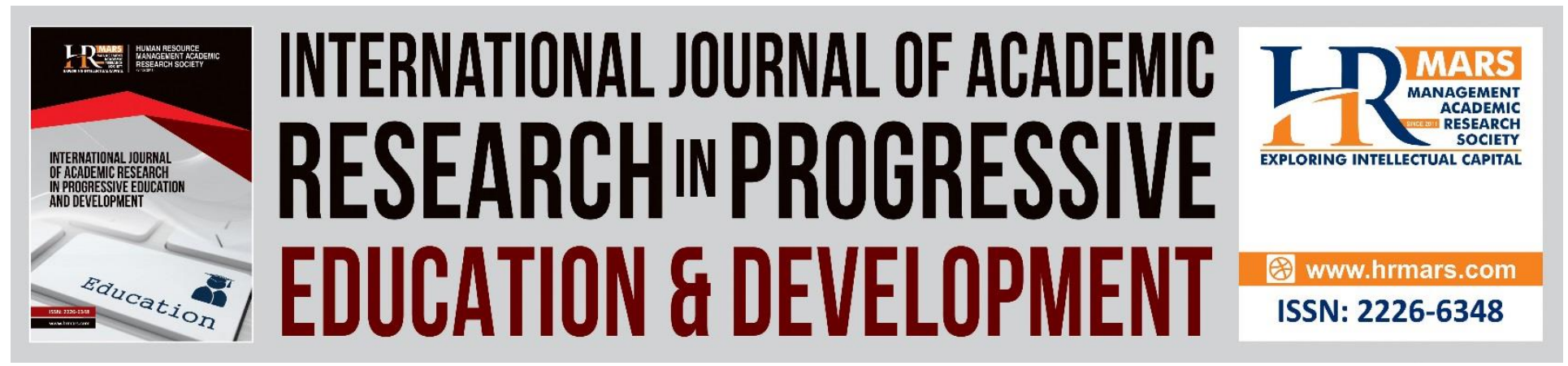

\title{
Improving Students' Achievement on Computational Thinking Skills Via Mobile Application Development Module
}

Letchumanan Shanmugam, Fariza Khalid, Wan Nur Wahidah Hashim, Norfida Erwani Binti Mohd Shafie

To Link this Article: http://dx.doi.org/10.6007/IJARPED/v10-i1/9228

DOI:10.6007/IJARPED/v10-i1/9228

Received: 10 January 2021, Revised: 12 February 2021, Accepted: 28 February 2021

Published Online: 26 March 2021

In-Text Citation: (Shanmugam et al., 2021)

To Cite this Article: Shanmugam, L., Khalid, F., Hashim, W. N. W., \& Shafie, N. E. B. M. (2021). Improving Students' Achievement on Computational Thinking Skills Via Mobile Application Development Module. International Journal of Academic Research in Progressive Education and Development, 10(1), 607-619.

Copyright: (C) 2021 The Author(s)

Published by Human Resource Management Academic Research Society (www.hrmars.com)

This article is published under the Creative Commons Attribution (CC BY 4.0) license. Anyone may reproduce, distribute, translate and create derivative works of this article (for both commercial and non-commercial purposes), subject to full attribution to the original publication and authors. The full terms of this license may be seen at: http://creativecommons.org/licences/by/4.0/legalcode

Vol. 10(1) 2021, Pg. 607 - 619

http://hrmars.com/index.php/pages/detail/IJARPED

JOURNAL HOMEPAGE

Full Terms \& Conditions of access and use can be found at http://hrmars.com/index.php/pages/detail/publication-ethics 


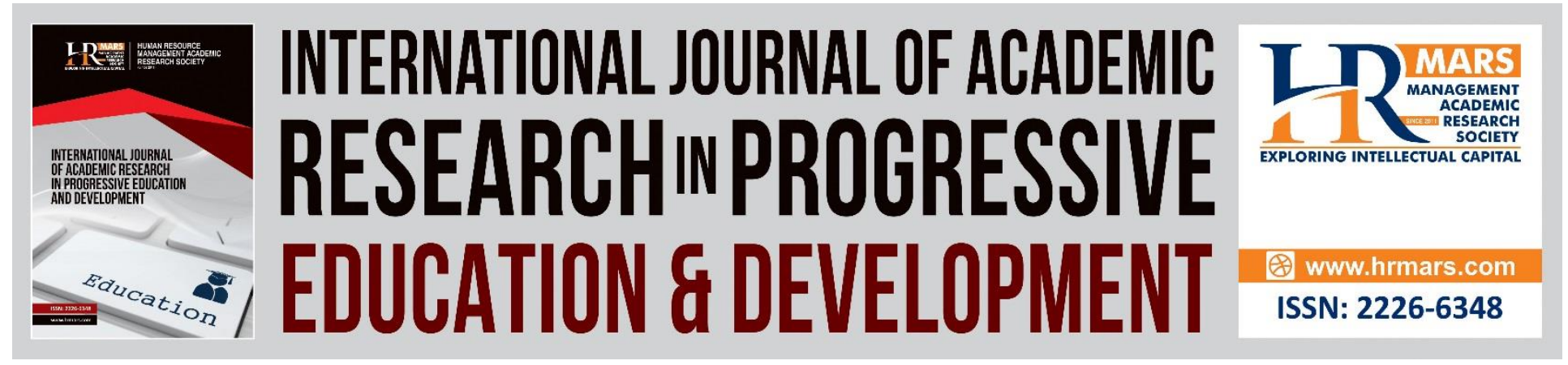

\title{
Improving Students' Achievement on Computational Thinking Skills Via Mobile Application Development Module
}

\author{
${ }^{1}$ Letchumanan Shanmugam, ${ }^{2}$ Fariza Khalid, ${ }^{3}$ Wan Nur Wahidah \\ Hashim, ${ }^{4}$ Norfida Erwani Binti Mohd Shafie \\ 1,3,4 Politeknik Balik Pulau, Pulau Pinang Malaysia, ${ }^{2}$ Universiti Kebangsaan Malaysia,Bangi \\ Selangor \\ Email: letchumanan@pbu.edu.my
}

\begin{abstract}
This research aims to enhance students' achievement on computational thinking skills through mobile application development module. Computational Thinking (CT) skills are a value that plays a role in highlighting the potential of an individual and who has advanced skills often will get more attention and respect than others. The design of this study is quasi-experimental. For this quasi experiment there are two groups of control and treatment. Both groups of respondents consisted of business administration students at one of the universities in Malaysia. The variables involved in this study are that the study groups use different methods of intervention; the treatment group used the module and the control group used the conventional method. Students' achievement in computational thinking skills was identified through the results of the analysis after intervention on 91 respondents. All respondents of this study are students as well as studying same course in University A. Before the post-test was conducted, the respondents involved in the study were tested for the homogeneity to reduce the internal and external threats. CT is a very interesting terminology and gets a good response among researchers. Most researchers have been aware and pay much attention to CT because most industries have started to focus on computational thinking skills as well as future work skills and one of the skills required among graduates is CT. Thus, we developed a mobile application development module to helps undergraduate students to learn and understand the concept of CT in well.
\end{abstract}

Keywords: Computational Thinking, Mobile Application Development Module,QuasiExperimental Research Design

\section{Introduction}

In earlier years, Computational Thinking (CT) was recognized in 1980 when Seymour Papert used CT as a specific term for developing cognitive skills to solve problems through programming (Lockwood \& Mooney, 2017; Romero, Lepage, \& Lille, 2017). The idea was additionally extended by J.M Wing in 2006 who considered CT to be a principal expertise and imagined computational 
thinking as a basic piece of early instruction for students. In the expanded concept, (Wing, 2006) stated that humans can emulate the devices' thinking process and come up with solutions. The importance of computational thinking was later realized by numerous researchers after it had positively impacted humans' academic and personal lives (Denning, 2009) and how it played a role in helping people to be more systematic and intelligent when analysing information (Lu \& Fletcher, 2009). In the field of education, computational thinking skills are used to enhance students' skills such as problem-solving, analytical, critical and creative abilities and innovative thinking as stated by the specific elements found in CT (Kules, 2016; Mohaghegh \& Mccauley, 2016; National Academies, 2014; Perkovi, Settle, \& Jones, 2010; Wing, 2006).

In the age of digital literacy, students should be creative, possess critical thinking skills, excellent interpersonal and social relations(Nor et al., 2016). Skills play a role in highlighting the potential of an individual. A person with advanced skills will get more attention and respect compared to others(Cukierman \& Palmieri, 2014). Students with these skill sets will have the ability to be successful in the society as they are able to solve problems and be contributors of ideas in the development of new world technologies (Heggen \& Cody, 2018; Kassan, Looi, \& Tham, 2016; Mohaghegh \& Mccauley, 2016). However, to ensure that CT is successfully implemented in the current education curriculum, it is necessary to incorporate various strategies, approaches and new teaching and learning methods that enable students to acquire and fully utilize CT skills. This view is supported by (Czerkawski \& Lyman, 2015; Ling, Saibin, Labadin, \& Aziz, 2017; Shanmugam \& Nadesan, 2019) who both stated the need to emphasize strategies, approaches, teaching and learning methods that allow the newly introduced CT concept to achieve its objectives of producing students equipped with knowledge, skills, creativity in thinking and innovativeness to face the challenges of the present and future.

Despite the strengths of incorporating computational thinking in the curriculum; a variety of designs is essential in the teaching of CT as the suitable design will facilitate in tapping CT's potential to broaden the way students think. Prior to the development of the module, it is noted that there are several mobile applications that could be integrated into the module. The advancement will go beyond games and robotic activities as the students will have the opportunity to learn and develop new applications via CT skills in App Inventor in this module. App Inventor is typical for students wishing to learn android applications. App Inventor is easy because the application can be developed through visual programming language.

\section{Literature Review}

\section{Computational Thinking Skills}

Skills are a value that play a role in highlighting the potential of an individual. A person who has advanced skills often will get more attention and respect than others (Ibharim, Yatim, \& Masran, 2015). Malaysia is the first country to introduce CT skills in the curriculum that wishes to develop students with the skills required by employers including creating a digital society not only in use but the formation (MDEC, 2019). In the context of education in Malaysia, the Ministry of Education (MOE) has identified CT skills with local contexts to provide Malaysians an analysis of things by providing systematic and logical solutions. It encourages a person to take a complex problem, analyse the causes of the problem and develop methods to make solutions. 
People with CT skills can help improve the country's economy and reduce unemployment rates through the existence of skilled individuals. CT skills emphasize on skills and capabilities for students, not on the content of STEM subjects (Breslow, 2015). CT skills emphasize problem solving skills to provide students with more creativity and critical thinking as well as enhance the students' existing capabilities and abilities. (IPGKPM, 2016) has identified CT skills to the local context in order to meet the aspirations of developing first class human capital in preparation for the challenges of the 21st century. (Mohaghegh \& Mccauley, 2016) state that 21st century skills can be developed through the elements of CT. 21st Century skills emphasize the creation of capable students in applying technology through digital literacy, creative and critical students in thought and possessing excellent interpersonal and social skills (Nor et al., 2016).

In the unpredictable global economic environment, it is better to prepare for the development of human capital that has the competence in skills, especially the skills required in the employers. Malaysia aims at enhancing productivity that can only be realized with technology-literate workforce groups and critical thinking skills to compete with the global economy of the 21st century (Ahmad, 2016). Education is a strong foundation which is the core of the labour force to produce a healthy, skilled and smart workforce to allow the country to compete successfully in world markets. The strategy will be implemented to make the school a platform to nurture creative thinking and learning skills that are essential to future manpower needs (MIHRM, 2017). According to (Ak \& Güvendi, 2010), education should not only address the repetition of what has been done by past or present generations, it is necessary to grow individuals through innovative skills. Education allows the individual to adapt to uncertain global changes and situations. Therefore, the Institution should provide a skilled human resource in line with the needs of the 21st century through CT skills. As defined by (NMC, 2015) 21st century literacy is a set of capabilities and skills that overlap between digital, visual and aural literacy. This includes the ability to recognize and use power to understand the power of image and voice, manipulate and transform digital media, disseminate information widely and adapt it to new forms more easily. Hence, the capabilities and skills of using technology and achieving information and interpreting them in understandable and global forms are indispensable in the 21st century. Therefore, the implementation of CT skills especially in the curriculum of higher education will speed up processing to achieve the goals of the 21st century.

In addition, the Fourth Industrial Revolution (4IR) was introduced in most of the developing countries wants to emphasize more on automation and robotic upgrades, Internet of Things (IOT), analysis and big data, system integration and cloud computing (Jantan, 2018; MITI, 2017; Shanmugam, Yassin, \& Khalid, 2019a). Therefore, we need to apply the technologies at all levels not only in business, but in almost all aspects of daily life. 4IR should be one of the transformations in higher education to produce students who can digitalize and innovate. The failure to introduce and implement the Industry revolution 4.0 policy led universities to lag behind in global competition (Sani, 2017; Shanmugam, Yassin, \& Khalid, 2019b). The goal of the industrial revolution can be achieved through computational thinking skills. Through these skills, students can create a variety of simulation or embedded systems that are more helpful to the industry.(WEC, 2016) states that the future of manufacturing will see an increased demand for cross-domain skills covering technology, engineering, electronics, robotics, usage of new equipment, computational thinking, coding and computer sciences. 
Vol. 10, No. 1, 2021, E-ISSN: 2226-6348 @ 2021 HRMARS

Industry 3.0 and 4.0 are more focused on the Information Technology (IT) field. IT fields are increasingly expanding because of receiving a lot of benefits from IT and directly assisting various sectors. Industry 3.0 emphasizes on the internet and server. This is very important in the industry to connect easily despite being away, especially international companies. Other than that, companies can store data in the server for the purposes of easy reference anytime and also it is more secure. In addition, the Fourth Industrial Revolution (4IR) is more focused on robotic creation, mobile application, cloud computing and that will help the economy of a country. By this, the development of the Industry requires skilled workers who can contribute to achieving the goals of the Industrial Revolution (IR).

Therefore, CT skills should be emphasized in the curriculum in higher education and this implementation will give more benefits to the students, the universities, industry and also to the country. Through this study, students will also enhance existing skills including learning how to develop mobile applications.

\section{Mobile Application Development}

Mobile technology has become a visible part of students' lifestyle nowadays(Dai, Teng, \& Bai, 2010). The development and advancement of mobile technology in education has grown rapidly without realizing. The development of the world in mobile technology has had a huge impact on the life of a student. This technology is made up of technological tools that are small and can be carried anywhere (Tucker, Tucker, \& Zheng, 2012). The use of smartphones is growing in the community. In Malaysia, the use of smartphones is $87.9 \%$ of the population for accessing the Internet and social media like Facebook, WeChat, WhatsApp, twitter and so on (MCMC, 2014). Additionally, the operating systems most popularly used in most of countries are Android and iOS. Android OS developed by Andy Rubin, Rich Miner, Nick Sears and Chris White in 2003 in California. In 2005, Google took over from them to expand Android usage (Khamlichi, 2015). iOS was developed by Steve Jobs in 2007 and it just supports Apple brand devices. Both operating systems are unique in accordance with the applications installed by the user. In addition, the operating system is very important for a smartphone to function perfectly. Mobile application consists of three types, namely Native Application, Mobile-web Application and Hybrid Application as shown in the Table 1 below:

Table 1

Feature of Native, Mobile-Web and Hybrid Application

\begin{tabular}{|c|c|c|c|}
\hline Features & Hybrid Application & Native Application & Web Apps \\
\hline Development Language & $\begin{array}{l}\text { HTML 5, Java Script } \\
\text { and SDK Tool }\end{array}$ & Native only & HTML 5 \\
\hline Performance & Good & Very Fast & $\begin{array}{l}\text { Depend on Web } \\
\text { Browser }\end{array}$ \\
\hline Code Portability & High & None & High \\
\hline User Interface & Moderate & High & Moderate \\
\hline
\end{tabular}




\section{Mobile Application Development Module}

The mobile application development module aims to help students learn and understand themselves about Computational Thinking (CT), how computer science materializes this thinking skills and how it can be integrated into a variety of subject areas. It increases students' awareness of CT, allows students to explore examples of CT that can be integrated into their daily routine task, experiment with examples of CT-integrated activities for their subject areas, create a plan to integrate CT to solve problems and enhance the motivation of CT skills.

It also emphasizes problem solving that utilizes students' prior knowledge in their subject area together with computational thinking skills to help them understand the nature and scope of a problem. The module also equips students with hands-on experience to ensure that the CT skills can be effectively delivered and transferred to them. For hands-on, this module integrated mobile application development and platform used is App Inventor. App Inventor is an intuitive, visual programming environment that allows everyone to build fully functional apps for smartphones and tablets. App Inventor uses blocks-based tools that allows anyone to programme more complex, impactful mobile apps without prior language skills (Kalelioglu, Gulbahar, \& Kukul, 2016). The App Inventor project seeks to democratize software development by empowering all people, especially young people, to make the transition from being consumers of technology to becoming creators of it (Sherman \& Martin, 2015).

Mobile technology has become a visible part of students' lifestyle nowadays. The development and advancement of mobile technology in education has grown rapidly without one realizing it. The development of the world in mobile technology has had a huge impact on the life of a student. Besides, App Inventor is typical for students wishing to learn Android Application. App Inventor is easy because it uses visual programming language. In addition, there are five activities in this module, including unplugged activities, as shown in Table 2. 
Vol. 10, No. 1, 2021, E-ISSN: 2226-6348 @ 2021 HRMARS

Table 2

Activity in Mobile Application Development Module

\begin{tabular}{|c|c|}
\hline Activity & Summary \\
\hline Unplugged Activity & $\begin{array}{l}\text { This activity introduces learners to } \\
\text { computational thinking by way of } \\
\text { exploration as a group pertaining to the } \\
\text { definition of computational thinking and the } \\
\text { elements contained in computational } \\
\text { thinking. }\end{array}$ \\
\hline Hyperlink App & $\begin{array}{l}\text { Apply computational thinking skills } \\
\text { elements to develop a mobile application } \\
\text { that shows links to search engine (google, } \\
\text { yahoo, ask and bing). }\end{array}$ \\
\hline Text_Reader App & $\begin{array}{l}\text { Modify the 'text_reader' application with } \\
\text { the features described below: } \\
\text { 1. Clear the text after reading } \\
\text { 2. If not insert the text into the textbox, } \\
\text { 'text_reader' app should alert the } \\
\text { user to insert the text } \\
\text { 3. Edit the elements of computational } \\
\text { thinking before developing the app }\end{array}$ \\
\hline Radio App & $\begin{array}{l}\text { Design radio application with the features } \\
\text { described below: } \\
\text { 1. Design flow chart based on } \\
\text { pseudocode } \\
\text { 2. Create the 'radio' app based on } \\
\text { elements of computational thinking } \\
\text { 3. Display the output in android phone }\end{array}$ \\
\hline Project & $\begin{array}{l}\text { The purpose of this activity is to encourage } \\
\text { learners to learn in-depth computational } \\
\text { thinking skills. In this activity, student is } \\
\text { required to discuss with the group members } \\
\text { and develop a new mobile application (if } \\
\text { any). In addition, they need to integrate } \\
\text { elements in ct such as abstraction, } \\
\text { algorithm, decomposition, pattern } \\
\text { recognition and evaluation. This process } \\
\text { needs to be presented to the instructor } \\
\text { before developing a mobile application. }\end{array}$ \\
\hline
\end{tabular}


INTERNATIONAL JOURNAL OF ACADEMIC RESEARCH IN PROGRESSIVE EDUCATION AND

DEVELOPMENT

Vol. 10, No. 1, 2021, E-ISSN: 2226-6348 @ 2021 HRMARS

\section{Research Hypotheses}

The null hypotheses constructed and tested in this study are:

$\mathrm{H}_{\circ 1}$ : There is no significant difference in mean scores in achievement of computational thinking skills between the control and treatment group

\section{Methodology}

In the methodology phase, a quasi-experimental design (non-equivalent control) was used in this research because the students are assigned according to their respective sections and if changes occur it would disrupt the timetables of the lecturers and students. (Campbell \& C.Stanley, 1963) stated that interruptions and problems will occur if researchers formed a new class with a random distribution concept in the study. Consequently, we used the existing classes and process of quasi-experimental design used in this study is shown in Table 3.

Table 3

The Design of Non-Equivalent Control Group

\begin{tabular}{llll}
\hline Group & Pre-Test & Intervention & Post-Test \\
\hline Control & $\mathrm{O}_{1}$ & Conventional & $\mathrm{O}_{2}$ \\
Treatment & $\mathrm{O}_{1}$ & Mobile Application & $\mathrm{O}_{2}$ \\
& & Development Module & \\
\hline
\end{tabular}

The respondents in treatment and control groups will sit for pre-test $\left(\mathrm{O}_{1}\right)$ before beginning a teaching and learning session on computational thinking topics. Subsequently, respondents in the control group learn computational thinking skills using conventional approaches and the learning materials are slides provided by instructor. The respondents in the treatment group are taught the same topics, but with integrated computational thinking skills into mobile application development. The variables involved in this study are that the study groups use different methods of intervention; the treatment group used the mobile application development module and the control group used the conventional method. At the end of the teaching and learning session, a post-test $\left(\mathrm{O}_{2}\right)$ will be conducted for both groups.

\section{Findings}

Pre-Test $-\mathrm{O}_{1}$

Achievement Test (Pre) was administered before the onset of the actual study process of 91 respondents. A total of 45 respondents were in the control group and 46 in the treatment group. Mean score of pre-control group achievement, $M=41.16(S D=14.368)$ while mean score of pretreatment group achievement, $M=41.43$ (SD = 16.603). Mean score of the pre-treatment group outperformed mean score of pre-achievement score of control group of 0.27 . Table 4 shows the mean descriptive statistic of pre-score by groups. 
INTERNATIONAL JOURNAL OF ACADEMIC RESEARCH IN PROGRESSIVE EDUCATION AND

DEVELOPMENT

Vol. 10, No. 1, 2021, E-ISSN: 2226-6348 @ 2021 HRMARS

Table 4 Descriptive statistics mean pre-achievements by groups

\begin{tabular}{llll}
\hline Group & Number of Respondents & Mean & Std. Deviation \\
\hline Control & 45 & 41.16 & 14.368 \\
Treatment & 46 & 41.39 & 16.519 \\
\hline
\end{tabular}

The homogeneity analysis of the achievement between the control and treatment groups was tested at a significant level of 0.05 to determine whether there was a difference in terms of achievement before the actual study was performed. Table 5 shows the results of the t-test of independent samples for the mean score of pre-group achievement.

Table 5 Results of the t-test and descriptive statistic for the Achievement Test (Pre) scores by Group (Control and Treatment)

\begin{tabular}{lllllll}
\hline Group & $\begin{array}{l}\text { Number of } \\
\text { Respondents }\end{array}$ & Mean & $\begin{array}{l}\text { Std. } \\
\text { Deviation }\end{array}$ & $\mathrm{t}$ & $\mathrm{df}$ & $\mathrm{Sig}$ \\
\hline Control & 45 & 41.16 & 14.368 & -0.073 & 89 & 0.942 \\
Treatment & 46 & 41.39 & 16.519 & & & \\
\hline
\end{tabular}

The results of Table 5 show that there is no significant difference in mean pre-score between control and treatment groups, $t=-0.073$ and $d f=89, p>0.05$. This shows that the control group and the treatment group are homogeneous in terms of achievement before treatment is performed because the differences in the means was very small.

\section{Post-Test- $\mathbf{O}_{2}$}

Achievements in computational thinking skills were obtained through Post-Achievement Testing administered after intervention on 91 respondents. A total of 45 people was in the control group and 46 in the treatment group.

a. Descriptive Statistics

Table 6 shows the mean descriptive statistic of Post Achievement score by group. Mean score of Post-Control Achievement, $M=55.58$ (SD = 6.625) while mean score of post-treatment achievement was $M=63.54$ ( $S P=11.045)$. Mean score Achievement Post treatment group exceeded the score mean score of the Post Achievement control group of 7.96.

Table 6 Mean descriptive statistics of post-test in achievement score

\begin{tabular}{lllll}
\hline Test & Group & $\mathrm{N}$ & Mean & Std. Deviation \\
\hline Post-Test & Control & 45 & 55.58 & 6.625 \\
& Treatment & 46 & 63.54 & 11.045 \\
\hline
\end{tabular}


Vol. 10, No. 1, 2021, E-ISSN: 2226-6348 @ 2021 HRMARS

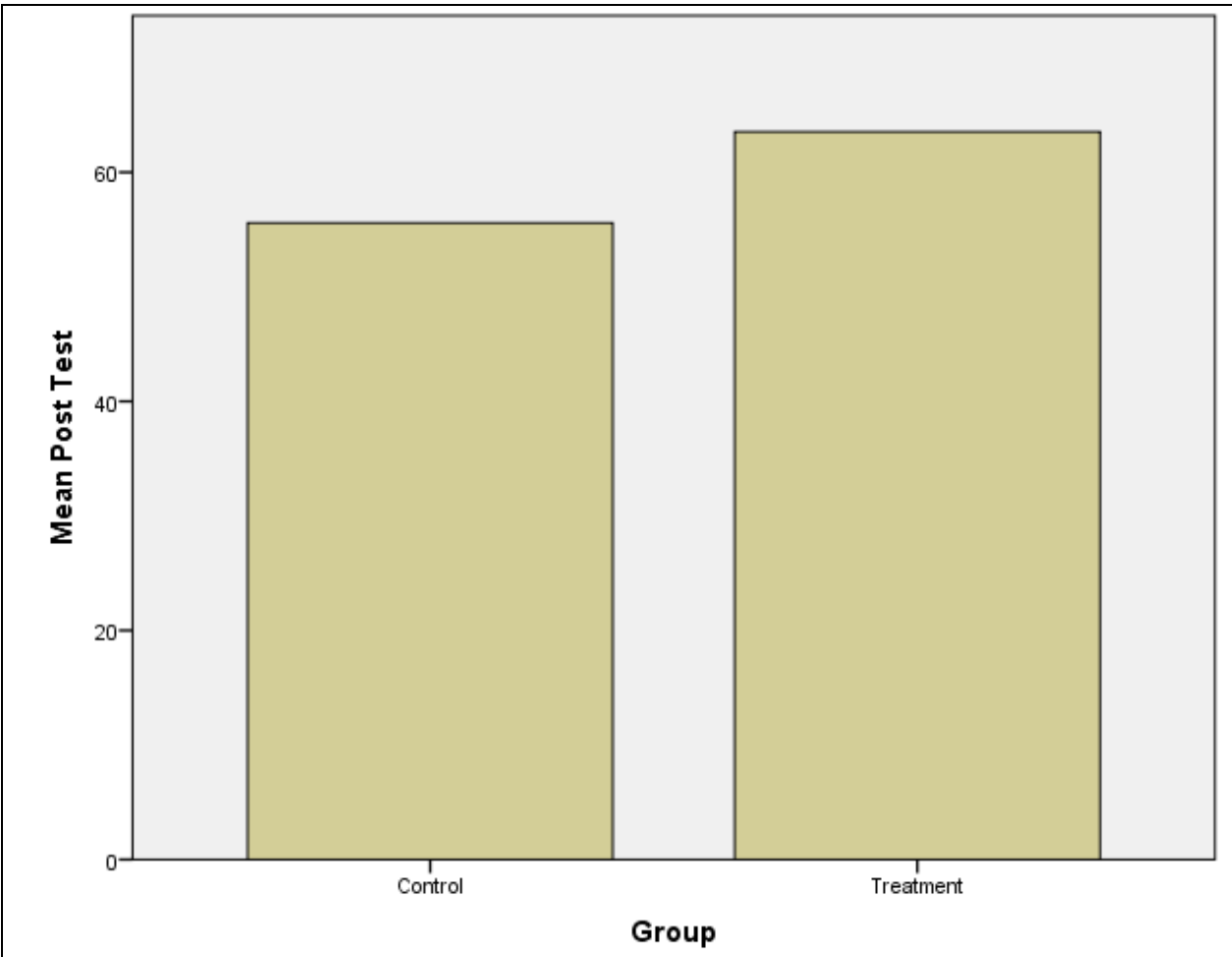

Figure 4.2 Mean score of post-tests in achievement score

$\mathrm{H}_{\mathrm{o1}}$ : There is no significant difference in mean scores in achievement of computational thinking skills between the control and treatment group

The hypothesis $\mathrm{H}_{01}$ was tested using the t-test of independent samples. Before the results of $\mathrm{t}$ test of independent variables, the Levene's test was first tested to determine whether there was a difference in terms of achievement after the actual study was performed. Table 6 gives Levene's test results for homogeneity variance for Post-Achievement Testing.

Table 6 Levene's test for homogeneity variance for Achievement Test

\begin{tabular}{llll}
\hline Dependent Variable & F & df & Sig. \\
\hline Achievement Test (Post) & 11.728 & 89 & 0.01 \\
\hline
\end{tabular}

Significant value in the Levene's test for Post Achievement Test was $0.001, p \leq 0.05$. This shows that the variance between control and treatment groups is not equal, the variances not assumed. Table 7shows the results of t-test of independent samples for the mean score of post achievement by group. 
INTERNATIONAL JOURNAL OF ACADEMIC RESEARCH IN PROGRESSIVE EDUCATION AND

DEVELOPMENT

Vol. 10, No. 1, 2021, E-ISSN: $2226-6348 @ 2021$ HRMARS

Table 7 Results of t-test of independent samples for mean score of post achievement by group.

\begin{tabular}{|c|c|c|c|c|c|c|}
\hline Group & $\begin{array}{l}\text { Number of } \\
\text { Respondent }\end{array}$ & Mean & $\begin{array}{l}\text { Std. } \\
\text { Deviation }\end{array}$ & $t$ & $d f$ & Sig \\
\hline Control & 45 & 55.58 & 6.625 & -4.161 & 89 & 0.01 \\
\hline Treatment & 46 & 63.54 & 11.045 & & & \\
\hline
\end{tabular}

Based on the mean score of the post, the treatment group is in control of the control group. Thus, the $\mathrm{H}_{01}$ hypothesis is denied based on a difference in mean scores in achievement of computational thinking skills between the control and treatment group. Thus, it can be concluded that the M-CT module is more effective than conventional methods in the achievement of computational thinking skills.

\section{Conclusion}

This paper is about enhancing students' achievement in CT skills through the mobile application development module. These skills are developed using a quasi-experiment design of conventional and mobile application for the control and treatment groups. Besides, Mobile Application Development is an exciting subject among students. Besides that, demand for mobile applications in all industry sectors is growing and it also directly helps increase the country's Gross Domestic Product (GDP) (Pacific, 2016). Other than that, most of the plans were introduced in countries either as Internet of Things (IOT), 21st century skills or as Industrial Revolutions. All of these strategies focus and emphasise digital technology, hence the reason why we used the mobile application development module in this paper. In the upcoming paper, we are going evaluate the effectiveness of a mobile application development module in motivation among undergraduate students on computational thinking skills using the Solomon four group design.

\section{References}

Ahmad, Z. (2016). Critical Thinking Skills, Creative Thinking Skills and Problem-solving Skills needed by Employers.

Ak, E., \& Güvendi, M. (2010). Assessment of the degree to which primary school teachers use alternative assessment and evaluation methods. Procedia - Social and Behavioral Sciences, 2(2), 5599-5604. https://doi.org/10.1016/j.sbspro.2010.03.913

Breslow, L. (2015). The pedagogy and pleasures of teaching a 21st-century skill. European Journal of Education, 50(4), 420-439. https://doi.org/10.1111/ejed.12159

Campbell, D. T., \& Stanley, C. J. (1963). Experimental and quasi-experimental designs for research. (N. L. Gage, Ed.) (Handbook o). Rand McNally.

Cukierman, U. R., \& Palmieri, J. M. (2014). Soft skills in engineering education: A practical experience in an undergraduate course. In 2014 International Conference on Interactive Collaborative Learning (ICL) (pp. 237-242). https://doi.org/10.1109/ICL.2014.7017776

Czerkawski, B. C., \& Lyman, E. W. (2015). Exploring Issues About Computational Thinking in Higher Education. TechTrends, 59(2), 57-65. https://doi.org/10.1007/s11528-015-0840-3

Dai, J., Teng, J., \& Bai, X. (2010). Mobile phone based drunk driving detection. ... ), 2010 4th International ..., 1-8. https://doi.org/10.4108/ICST.PERVASIVEHEALTH2010.8901 
Denning, P. J. (2009). Beyond Computational Thinking.

Heggen, S., \& Cody, M. (2018). Hiring Millennial Students as Software Engineers: A Study in Developing Self-Confidence and Marketable Skills. In 2018 IEEE/ACM International Workshop on Software Engineering Education for Millennials (SEEM) (pp. 32-39).

Ibharim, L. F. M., Yatim, M. H. M., \& Masran, M. N. (2015). Menerokai Kemahiran Abad Ke-21 Kanak- Kanak dalam Proses Reka Bentuk Permainan Penceritaan Digital ( Exploring 21st ... Journal of Science, Mathematic and Technology, 2(1), 82-96. https://doi.org/10.13140/RG.2.1.1491.3360

IPGKPM. (2016). Modul TMK dan pemikiran komputasional untuk KSSR.

Jantan, A. H. (2018). FOURTH INDUSTRIAL REVOLUTION IN DEVELOPING COUNTRIES : A CASE ON FOURTH INDUSTRIAL REVOLUTION IN DEVELOPING COUNTRIES: A CASE ON Md Asadul Islam , Universiti Putra Malaysia, (January), 0-9.

Kalelioglu, F., Gulbahar, Y., \& Kukul, V. (2016). A Framework for Computational Thinking Based on a Systematic Research Review. Baltic Journal of Modern Computing, 4(3), 583-596.

Kassan, S., Looi, K. F., \& Tham, Y. M. (2016). Asas Sains Komputer.

Khamlichi, M. E. (2015). The History Of Android.

Kules, B. (2016). Computational Thinking is Critical Thinking : Connecting to University Discourse , Goals, and Learning Outcomes.

Ling, U. L., Saibin, T. C., Labadin, J., \& Aziz, N. A. (2017). Preliminary Investigation: Teachers' Perception on Computational Thinking Concepts. Journal of Telecommunication, Electronic and Computer Engineering, 9(2), 2289-8131.

Lockwood, J., \& Mooney, A. (2017). Computational Thinking in Education : Where does it fit ? A systematic literary review Table of Contents, 1-58.

Lu, J. J., \& Fletcher, G. H. L. (2009). Thinking about computational thinking. In Proceedings of the 40th ACM technical symposium on Computer science education (pp. 260-264).

MCMC. (2014). Hand Phone User Survey.

MDEC. (2019). Computational Thinking.

MIHRM. (2017). Creativity, problem solving \& leadership skills.

MITI. (2017). Trade Performance for The Month of September 2017. Ministry of International Trade and Industry, 35-38.

Mohaghegh, M., \& Mccauley, M. (2016). Computational Thinking : The Skill Set of the 21st Century, 7(3), 1524-1530.

National Academies. (2014). How people learn: Brain, mind, experience and school.

NMC. (2015). The report of the 21st century literacy summit. Adobe Systems, Incorporated.

Nor, W., Wan, F., Arsad, N. M., Othman, O., Halim, L., Rasul, M. S., ... Iksan, Z. (2016). Fostering students' 21st century skills through Project Oriented Problem Based Learning (POPBL) in integrated STEM education program, 17(1).

Pacific, A. (2016). The Mobile Economy.

Perkovi, L., Settle, A., \& Jones, J. (2010). A Framework for Computational Thinking across the Curriculum. In Proceedings of the fifteenth annual conference on Innovation and technology in computer science education (pp. 123-127). https://doi.org/10.1145/1822090.1822126

Romero, M., Lepage, A., \& Lille, B. (2017). Computational thinking development through creative programming in higher education. International Journal of Educational Technology in Higher 
Education, 14(1), 42. https://doi.org/10.1186/s41239-017-0080-z

Sani, M. A. M. (2017). R\&D universiti katalis Revolusi Industri 4.0. Berita Harian, p. 10.

Shanmugam, L., \& Nadesan, G. (2019). An Innovative Module for Learning Computational Thinking Skills among Undergraduate Students. International Journal of Academic Research in Progressive Education \& Development, 8(4), 116-129. https://doi.org/10.6007/IJARPED/v8-i4/6440

Shanmugam, L., Yassin, S. F., \& Khalid, F. (2019a). Enhancing Students ' Motivation to Learn Computational Thinking through Mobile Application Development Module ( M-CT ). International Journal of Engineering and Advanced Technology, 8(5), 1293-1303.

Shanmugam, L., Yassin, S. F., \& Khalid, F. (2019b). Incorporating the Elements of Computational Thinking into the Mobile Application Development Life Cycle ( MADLC) Model. International Journal of Engineering and Advanced Technology, 8(5), 815-824.

Sherman, M., \& Martin, F. (2015). The assessment of mobile computational thinking. Journal of Computing Sciences in Colleges, 30(6), 53-59.

Tucker, C., Tucker, R., \& Zheng, J. (2012). StopWatcher: A mobile application to improve stop sign awareness for driving safety. International Journal of Vehicular Technology, 2012. https://doi.org/10.1155/2012/532568

WEC. (2016). Manufacturing Our Future Cases on the Future of Manufacturing.

Wing, J. M. (2006). ComputationalThinking. Communications of the ACM, 49(3), 33-35. 